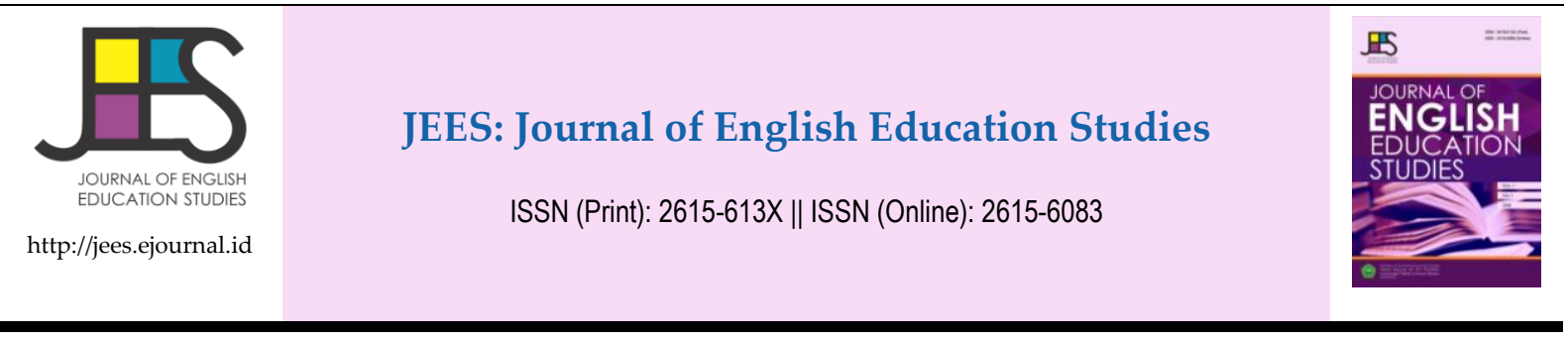

\title{
Freshmen's Perception on Inductive Approach Through PPP (Presentation, Practice, Production) Phase in Their First Speaking Class
}

\author{
Erna Irawati ${ }^{1}$
}

${ }^{1}$ English Education Study Program, Teacher Training and Education Faculty of Universitas Mathla'ul Anwar

\begin{tabular}{|c|c|}
\hline ARTICLE INFO & ABSTRACT \\
\hline $\begin{array}{l}\text { Keywords: } \\
\text { Inductive Approach } \\
\text { PPP Phase } \\
\text { Speaking Class }\end{array}$ & $\begin{array}{l}\text { This research investigates freshmen's perception on inductive approach through PPP } \\
\text { phase in their first speaking class. The researcher tries to integrate the previous students } \\
\text { learning experience that were accustomed to the deductive approach with the inductive } \\
\text { approach as the solution by implementing the PPP phase. The research is based on } \\
\text { qualitative approach with descriptive method. } 38 \text { first semester students from English } \\
\text { Education Study Program of teacher Training and Education Faculty, Universitas } \\
\text { Mathla'ul Anwar Banten were assigned as participants. Questionnaire was evaluated to } \\
\text { get insight about freshmen's perception on Inductive Approach through PPP phase in } \\
\text { their first speaking class. As a result, the study reveals that the student's response to all } \\
\text { aspects of learning get a high response, } 83.11 \% \text { for inductive approach, } 95.39 \% \text { for PPP } \\
\text { phase, and } 100 \% \text { for speaking activity. As the final remark, this means that students give } \\
\text { a positive response on inductive approach through PPP phase in their first speaking class } \\
\text { with the average score of all aspects } 92.84 \% \text {. }\end{array}$ \\
\hline
\end{tabular}

This is an open access article distributed under the terms of the Creative Commons Attribution 4.0 International License, which permits unrestricted use, distribution, and reproduction in any medium, provided the original work is properly cited. @ 2018 Erna Irawati.

\section{INTRODUCTION}

For freshmen of English Education Study Program, in which English is their foreign language, speaking class is considered as a challenging class compared to other classes. The speaking class, as the name implies, requires students to actively talk and engage in class discussions, of course, using English. However, they face difficulties in doing so. Some factors behind their difficulties to play an active role in the classroom are: they have not been accostumed to speak English inside or outside the classroom, excessive use of mother tongue (Bahasa Indonesia), and lack of time to practice English. This data is obtained from informal interview to them at the beginning of speaking class.

Other data obtained from the study of (Ashfar, 2016: 120), some of the speaking skills problems reported by the freshmen are associated with the instructors' teaching methodology, being afraid of making mistakes and lack of vocabulary knowledge. Freshmen, in addition to not accostumed

\footnotetext{
${ }^{1}$ Corresponding author's address: English Education Study Program of Teacher Training and Education Faculty, Universitas Mathla'ul Anwar, Banten, Indonesia e-mail: ernairakarim@gmail.com
} 
yet with full English in the classroom, they also experience the limitations of vocabulary and grammar in expressing their ideas in the classroom.

Speaking is one of the primary elements of communication. In EFL contexts, it requires special attention and instruction, (Afshar, 2016: 114). In line with this, Irawati (2015: 46) states that speaking is a complex activity that requires the right way in its learning. Speaking I class is designed to develop students' English skills in a variety of daily communication topics. Students are required to engage in daily conversations in different situations based on various topics and activities in basic communication. Therefore speaking class should be a fun class with a variety of easy class activities and makes freshmen feel easy to get involved and take an active role in the speaking class.

Nowadays, an inductive approach is emphasized to students with no concept explanation. It is in reverse with the freshmen's habit. Sik in his article (2015: 2142) argues that in grammar teaching, inductive approach is labeled as modern approach and deductive approache is described as traditional approach. The former teaching approach they got used to is deductive approach which involved rules explanation at the beginning before their practice. So, they need an introduction to inductive approach since they have not been familiar with the approach because they feel more comfortable with a deductive approach before. The present research introduces them with inductive approach integrated to PPP phase which identically associated with deductive approach. The purpose is to acknowledge freshmen's perception on this approach through PPP phase in their first speaking class.

The researcher tries to integrate the previous students learning experience that were accustomed to the deductive approach with the inductive approach as the solution by implementing the PPP phase. This model with the phases of presentation, practice, and production is suitable for the lower level students where there is still presentation phase but with no explanation about concept. By incorporating an inductive approach to the PPP model, at the presentation phase the lecturer no longer provides a rule or formula or concept explanation for the student but presents the student many examples showing how the concept is used. It is intentionally applied to get students pay attention on how the concept works through examples. The next phase is certainly more student centre where in practice phase students are given a lot of activity but more on drilling through exercises. Ends with a production phase where students' speaking skills are more demanded by giving many activities such as simulation, describing something, role play, interview, etc.

Baker (2000: 23) points that:

One of the best ways of helping students to reach the objectives of the lesson is to introduce the new language well in the first phase of the lesson: this is "the presentation phase". Then, students need to have "plenty of activities" to help them practice the new language: this is "the practice phase". Lastly, it takes times for the students to use the new language they have learned in order to communicate each other: this is "the production phase".

\section{METHOD}

This research uses qualitative approach with descriptive method. A qualitative approach is based on constructivist perspective or participatory perspective or both using strategies of inquiry such as narrative or descriptive, phenomenologies, ethnographies, grounded theory studies, or case studies in which researcher collects open-ended and emerging data, (Creswell, 2003: 18). The instrument used to collect data is a questionnaire given to freshmen, 38 semester 1 students of English Education Study Program of Teacher Training and Education Faculty, Universitas Mathla'ul Anwar Banten. Questionnaire includes 9 questions from 3 main areas (inductive approach, PPP phase, and speaking activity) with scale items to have a general idea about freshmen's perception of a statement divided into 4 categories ranging from Strongly Agree (SA), Agree (A), Disagree (D), and Strongly Disagree 
(SD). Positive and negative statements were included to minimize bias response. This research is run by step or procedure of research as follows: make questionnaire, data processing through computer by using Microsoft Excell, the result of data processing subsequently used for data analysis, after that it is interpreted to find meaning and broader implication of research result and generalized to draw conclusion.

The questionnaire statements are:

1. Inductive approach is interesting.

2. I feel challenged when lecturer lets me construct the concept.

3. I get difficulties when lecturer does not explain the concept.

4. PPP phase is interesting.

5. PPP phase helps me understand the material.

6. PPP phase does not suit with me.

7. I always get turn to speak in speaking class.

8. Inductive approach through PPP is effective to make us active and collaborative.

9. I do not like learning speaking by using inductive approach through PPP.

\section{RESULT AND DISCUSSION}

This research has been completed in Semester I students of English Education Study Program consisting of 38 students held from August 25 to December 18, 2017. The table below shows the result of freshmen's perception on three main aspects: inductive approach; PPP phase and speaking activity, therefore data were analyzed and discussed into three parts.

Table 1. Result of Freshmen's Perception on Inductive Approach through PPP Phase in Speaking Class

\begin{tabular}{|c|c|c|c|c|}
\hline \multirow[t]{2}{*}{ Aspect } & \multirow[t]{2}{*}{$\begin{array}{l}\text { Number of } \\
\text { question }\end{array}$} & \multicolumn{3}{|c|}{$\begin{array}{l}\text { The average score of freshmen's } \\
\text { perception }\end{array}$} \\
\hline & & Item & Percentage & Class \\
\hline \multirow[t]{3}{*}{ Inductive Approach } & 1 & 3.03 & $75.66 \%$ & $83.11 \%$ \\
\hline & 2 & 4.00 & $100.00 \%$ & \\
\hline & 3 & 2.95 & $73.68 \%$ & \\
\hline \multirow[t]{3}{*}{ PPP Phase } & 4 & 4.00 & $100.00 \%$ & $95.39 \%$ \\
\hline & 5 & 3.61 & $90.03 \%$ & \\
\hline & 6 & 3.84 & $96.05 \%$ & \\
\hline \multirow[t]{3}{*}{ Speaking Activity } & 7 & 4.00 & $100.00 \%$ & $100.00 \%$ \\
\hline & 8 & 4.00 & $100.00 \%$ & \\
\hline & 9 & 4.00 & $100.00 \%$ & \\
\hline Average & & & & $92.84 \%$ \\
\hline
\end{tabular}

Data obtained from the table gives the information that students' perception in all aspects get a high response. This means that students give a positive response to speaking class which applying inductive approach through PPP phase. 
The item analyses of the questionnaires show that:

1) Inductive approach is perceived as an interesting way of learning English by the majority $(75.66 \%)$ of freshmen. Although there are still several students who disagree, but some of them state that learning speaking beginning by the example of the use of target language guides the learners noticing the concept themselves and that way is interesting.

2) All students (100\%) think that inductive approach is challenging in which they have to construct the concept by themselves. It's a concept-discovery path. The students study some examples and then try to discover an understanding of the concept. They do not meet ready-made concept to be learnt. The concept will be generalized in the production phase where students in turn produce the concept and will realize the correct or the wrong by noticing other friends' production with lecturer's referrals and feedback.

This way of learning is considered challenging by the learners because they have not been accostumed yet with inductive approach. Notwithstanding, this is good for the learners to build their critical thinking by making learning their own. The lecturer's role is just a facilitator. By refraining not to explain the concept being learned, it restores the true nature of learning that must be experienced by the students which will cause to emerge the learners' critical thinking and problem solving.

3) Although some learners still get difficulties when lecturer does not explain the concept, most learners $(73.68 \%)$ get deeper understanding when they own their learning and feel better when they are in this speaking class form.

4) The whole class agree $(100 \%)$ that PPP phase is interesting. The researcher customizes the phase to students' needs and condition. Byrne in Anderson (2017: 221) suggested that the stages order of PPP could be flexible. The main aim is to get the learners to communicate, we can reverse the sequence by first set the students tasks which require them to communicate with the language and then use the outcome as a way of deciding what target language needs to be presented and perhaps further practiced.

In this study, speaking class with inductive approach through PPP (presentation, practice, production) implements some additional steps within by not changing the core of PPP itself as follows:

\section{Presentation}

Researcher add warmer up or ellicitation as an initial activity. It varies from watching short movie; giving them ridles or game; singing a song; and so on, follows up by presentation not by presenting the concept or material but by demonstrating the language through examples. So, this phase consists of two activities: introductory activity and the introduction of the material.

\section{Practice}

This is the checking concept phase. The lecturer gives students a lot of practices to check students' understanding about the concept. The practice encourages learners to actively collaborate and communicate in class to accomplish the exercise. In this phase, the researcher inserts consolidation to reinforce the material before the students practice it. Consolidation is given prior to production to maximize student output while speaking. As Ribawa (2016: 109) says that the repetition of material will reinforce the material that leads students to respond well in the production phase.

\section{Production}

Production phase is students' time to perform. Students in turn perform the functional language with no interference from the teacher. Students who are still wrong in using target language will notice the mistake and discover the correct use of language by paying attention to their friends who are correct by repeating the utterance pointed by the lecturer.

5) High percentage of learners (90.03\%) believe that PPP phase helps them understand the material being studied and becomes much easier to practice after being aware of the concept.

6) PPP phase is most preferred by the learners (96.05\%). Only very few of the learners who think that learning speaking by using inductive approach through PPP phase does not suit with them. 
7) All students (100\%) confess that they always get turn to speak in speaking class with inductive approache through PPP phase applied. In production phase, lecturer leads all students to speak up, the rest will pay attention to their friend's utterance to convince and confirm their own understanding by noticing lecturer's referral and feedback to learners.

8) Class agrees $(100 \%)$ that inductive approach through PPP is effective to make them active and collaborative. Practice phase makes students learn individually and collaboratively engage in speaking class. This phase needs lecturer's creativity to provide worksheets or exercises that make students active, communicative and collaborative in class.

9) It is reported that all learners (100\%) like learning speaking by using inductive approach through PPP phase.

\section{CONCLUSION}

Conclusion reached as the result of data analysis in this research is freshmen's perception on inductive approach through PPP phase in spekaing class. From the above table of freshmen's perception and its explanation, it is obtained information that the student's response to all aspects of learning get a high response, $83.11 \%$ for inductive approach, $95.39 \%$ for PPP phase, and $100 \%$ for speaking activity. As the final remark, this means that students give a positive response on inductive approach through PPP phase in their first speaking class with the average score of all aspect $92.84 \%$.

\section{REFERENCES}

Anderson, J. (2017). A Potted History of PPP with The Help of ELT Journal. ELT Journal, 17(2), 218227.

Ashfar, H. S. (2016). Speaking Skill Problems Encountered by Iranian EFL Freshmen and Senior from Their Own and Their English Instructor's Perspective. Journal of Foreign Language Teaching, 13 (1), 112-130.

Baker, J., and Westrup, H. (2000). The English Language Teacher's Handbook. London: Continuum.

Creswell, J. W. (2003). Research Design: Qualitative, Quantitative, and Mixed Methods Approach. London: Sage Publication.

Irawati, E. (2015). The Effects of Teaching Model and Learning Styles toward Students' Speaking Skill at Private Schools in Rangkasbitung. Mendidik, 1(1), 45-52.

Ribawa, I. K. O. (2016). Penerapan Metode PPP (Presentation, Practice, and Production) dalam Pembelajaran Menulis Teks Deskriptif Kelas VII SMP PGRI 4 Denpasar. Linguistika, 23(44), 97109.

Sik, K. (2015). Tradition or Modernism in Grammar Teaching: Deductive Vs. Inductive Approaches. Procedia, Social and Behavioral Sciences, 197, 2141-2144. 